\title{
Animal related facial trauma
}

\section{Urazy twarzy wywołane przez zwierzęta}

\author{
Aneta Neskoromna-Jędrzejczak ${ }^{1, A, E, F}$, Bogusław Antoszewski2, E, F, Katarzyna Bogusiakk ${ }^{1, A-D}$ \\ 1 Department of Craniomaxillofacial and Oncological Surgery, Medical University of Lodz, Łódź, Poland \\ 2 Department of Plastic, Reconstructive and Aesthetic Surgery, Medical University of Lodz, Łódź, Poland \\ A - research concept and design; B - collection and/or assembly of data; $\mathrm{C}$ - data analysis and interpretation; \\ $\mathrm{D}$ - writing the article; $\mathrm{E}$ - critical revision of the article; $\mathrm{F}$ - final approval of article
}

\section{Address for correspondence}

Katarzyna Bogusiak

E-mai: katarzyna.bogusiak@gmail.com

\section{Funding sources}

none declared

Conflict of interest

none declared

Received on 0ctober 1, 2016

Revised on January 8, 2017

Accepted on January 9, 2017

\section{Abstract}

Background. According to ICD-10 classification, animal related injuries may result from being bitten or hit, not to mention being stung or crushed by an animal.

Objectives. The aim of the study is to analyze and characterize animal related injuries.

Material and methods. 35 patients (13 men and 22 women) treated at Craniomaxillofacial and Oncological Surgery Department in MU of Lodz between 2004 and 2012 due to animal related injuries were enrolled into the study. The age of patients ranged between 15 and 75 years. A retrospective analysis focusing on medical documentation enabled us to collect data concerning the following: age of patients, gender of patients, animal that caused the injury, the site of the accident, alcohol consumption by the injured individual prior to the incident, as well as the period of hospitalization. Additionally, the FISS scale (Facial Injury Severity Scale) was used to evaluate the severity of facial injuries.

Results. Results lead to observations making it possible to declare that men suffered from injuries reported as severe according to the FISS scale much more frequently than women. More severe injuries also occurred significantly more often in agricultural farms. Injuries caused by large home animals are related with the incidence of the so-called high-energy injuries and stand as frequent multi-organ and multi-site injuries.

Conclusions. Animal related injuries are often multi-organ and multi-site injuries that require specialist treatment. More severe injuries were observed both in the masculine group and within the area of agricultural farms. The greater value of the FISS scale was associated with a longer period of hospitalization. Alcohol consumption is emphasized as a factor prompting the attack of the animal, as well as animal aggression against a human being.

Key words: animal related injuries, face trauma, Facial Injury Severity Scale

Słowa kluczowe: urazy odzwierzęce, uraz twarzy, Skala Ciężkości Urazów Twarzy

D0I

$10.17219 / \mathrm{dmp} / 68379$

Copyright

○ 2017 by Wroclaw Medical University

and Polish Dental Society

This is an article distributed under the terms of the

Creative Commons Attribution Non-Commercial License

(http://creativecommons.org/licenses/by-nc-nd/4.0/) 
According to ICD-10 classification, animal related injuries may result from being bitten or hit, not to mention being stung or crushed by an animal. The frequency and type of animal related injuries differ depending on the region of the world, which is related with the occurrence of specific fauna within a given area. In the United Arab Emirates frequently reported injuries include the ones caused by camels (212 such traumas have been reported during the years 2003-2012), whereas in Kashmir bear attacks seem to be the most problematic issue (on average, causing about 50 injuries a year). ${ }^{1,2}$ In the USA, where statistical information associated with animal related injuries has the best documentation, about 1.3 million animal related injuries are reported annually, where the most common reasons why injured people report to physicians include traumas caused by arthropods $-50 \%$, dogs $-24 \%$ of all injuries. It has been calculated that about 200-500 people die every year due to animal related injuries. As far as the global perspective is concerned, we can observe an increasing number of dog bites, and in the USA about 9,500 patients are hospitalized for longer than one day because of being bitten by a dog, and what is more, in the USA and Canada more than 500 deaths are reported due to the above. ${ }^{3-5}$

According to the data provided by the Agricultural Social Insurance Fund (pol. Kasa Rolniczego Ubezpieczenia Społecznego - KRUS), more than 2,800 people were treated in Poland in 2012 as a result of being hit, bitten or crushed by animals. ${ }^{6}$ Literature indicates a slight percentage of deadly dog bites - several cases each year. ${ }^{7}$ Such injuries constituted from about 2.5 to $8 \%$ of all reasons underlying traumas in Poland. 7,8

The aim of this study was to analyze and characterize animal related injuries.

\section{Materials and methods}

35 patients (13 men and 22 women) treated at Craniomaxillofacial and Oncological Surgery Department in MU of Lodz between 2004-2012 due to animal related injuries were enrolled into the study. The age of patients ranged between 15 and 75 years of age - the average age in the whole group equaled 38.56 years \pm 16.6 , whereas in the group of women the average age was 40.14 years \pm 16.62 and in the male group it reached 25.92 years \pm 16.01 . A retrospective analysis focusing on medical documentation enabled us to collect data concerning the following: age of patients, gender of patients, animal that caused the injury, the site of the accident, alcohol consumption by the injured individual prior to the incident, as well as the period of hospitalization. Additionally, the FISS scale (Facial Injury Severity Scale) was used to evaluate the severity of facial injuries, as it enumerates 4 main groups covering certain traumas: soft tissue injuries, upper face height injuries, middle face height injuries and lower face height injuries (Table 1). ${ }^{9}$
Table 1. Facial Injury Severity Scale

\begin{tabular}{|c|c|c|}
\hline Parameter & & Points \\
\hline \multicolumn{3}{|l|}{ Soft tissue injuries (facial laceration) } \\
\hline & $\leq 10 \mathrm{~cm}$ & 0 \\
\hline & $>10 \mathrm{~cm}$ & 1 \\
\hline \multicolumn{3}{|l|}{ Upper face height injuries } \\
\hline Fracture of orbital roof/rim & & 1 \\
\hline \multirow[t]{2}{*}{ Fracture of frontal sinus/bone } & displaced & 5 \\
\hline & nondisplaced & 1 \\
\hline \multicolumn{3}{|l|}{ Middle face height injuries } \\
\hline \multirow[t]{3}{*}{ Maxillary fracture } & Le Fort I & 2 \\
\hline & Le Fort II & 4 \\
\hline & Le Fort III & 6 \\
\hline \multicolumn{3}{|c|}{ Unilateral maxillary fracture are appointed half of points } \\
\hline Dento-alveolar injury & & 1 \\
\hline $\begin{array}{l}\text { Naso-orbital-ethmoid complex } \\
\text { fractures }\end{array}$ & & 3 \\
\hline $\begin{array}{l}\text { Zygomatico-maxillary complex } \\
\text { fractures }\end{array}$ & & 1 \\
\hline Isolated nasal bone fracture & & 1 \\
\hline \multicolumn{3}{|l|}{ Lower face height injuries } \\
\hline Dento-alveolar injury of mandible & & 1 \\
\hline $\begin{array}{l}\text { Fractures of mandible body, ramus/ } \\
\text { symphysis }\end{array}$ & & $\begin{array}{l}2 \times \text { number of } \\
\text { fracture fissures }\end{array}$ \\
\hline $\begin{array}{l}\text { Fracture of mandibular subcondyle, } \\
\text { condyle or coronoid process }\end{array}$ & & 1 \\
\hline
\end{tabular}

\section{Statistical analysis}

In order to verify statistical dependencies, all collected results were analyzed with a $\chi^{2}$ test. $\mathrm{P}<0.05$ value was assumed as a predetermined significance level.

\section{Results}

The group of hospitalized patients suffered injuries caused by the following animals: dog (26 cases), horse ( 8 cases) and a bull (1 case). The majority of traumas caused by animals resulted in the occurrence of bite wounds (26 people) (Fig. 1 and 2). Facial bone fractures were diagnosed in the case of 9 individuals. 4 patients with facial bone fractures also suffered from facial wounds (Fig. 3).

The majority of people, namely 27 (0.77 fraction), experienced light injuries that were evaluated as $0-1$ on the FISS scale. Facial wounds dominated within this group of patients (21 people), and they most commonly covered more than just one area of the face. No concomitant injuries were reported in this group of patients. As far as 8 people are concerned, traumas were classified as points 2-6 on the FISS scale. Men dominated this group. 3 pa- 

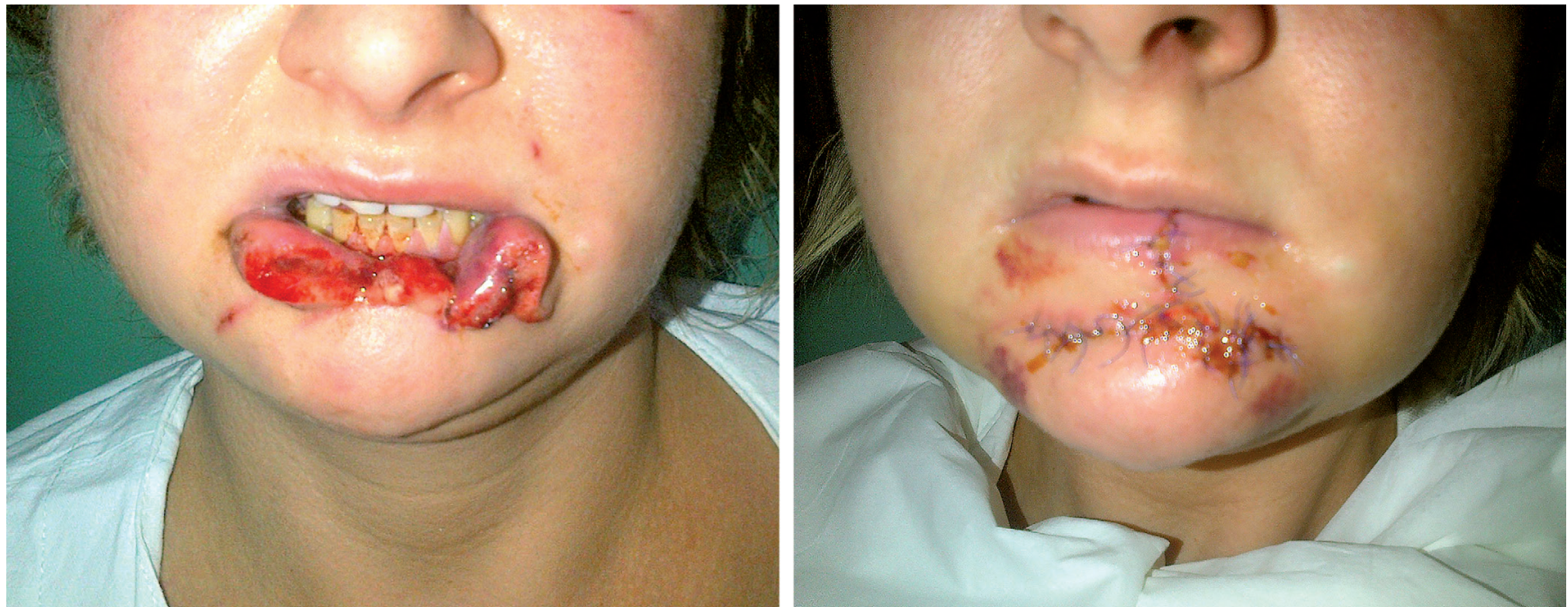

Fig. 1. Woman, 37 years old. The wounds of the lower lip with tissue loss caused by dog bites. Reconstruction of the lower lip
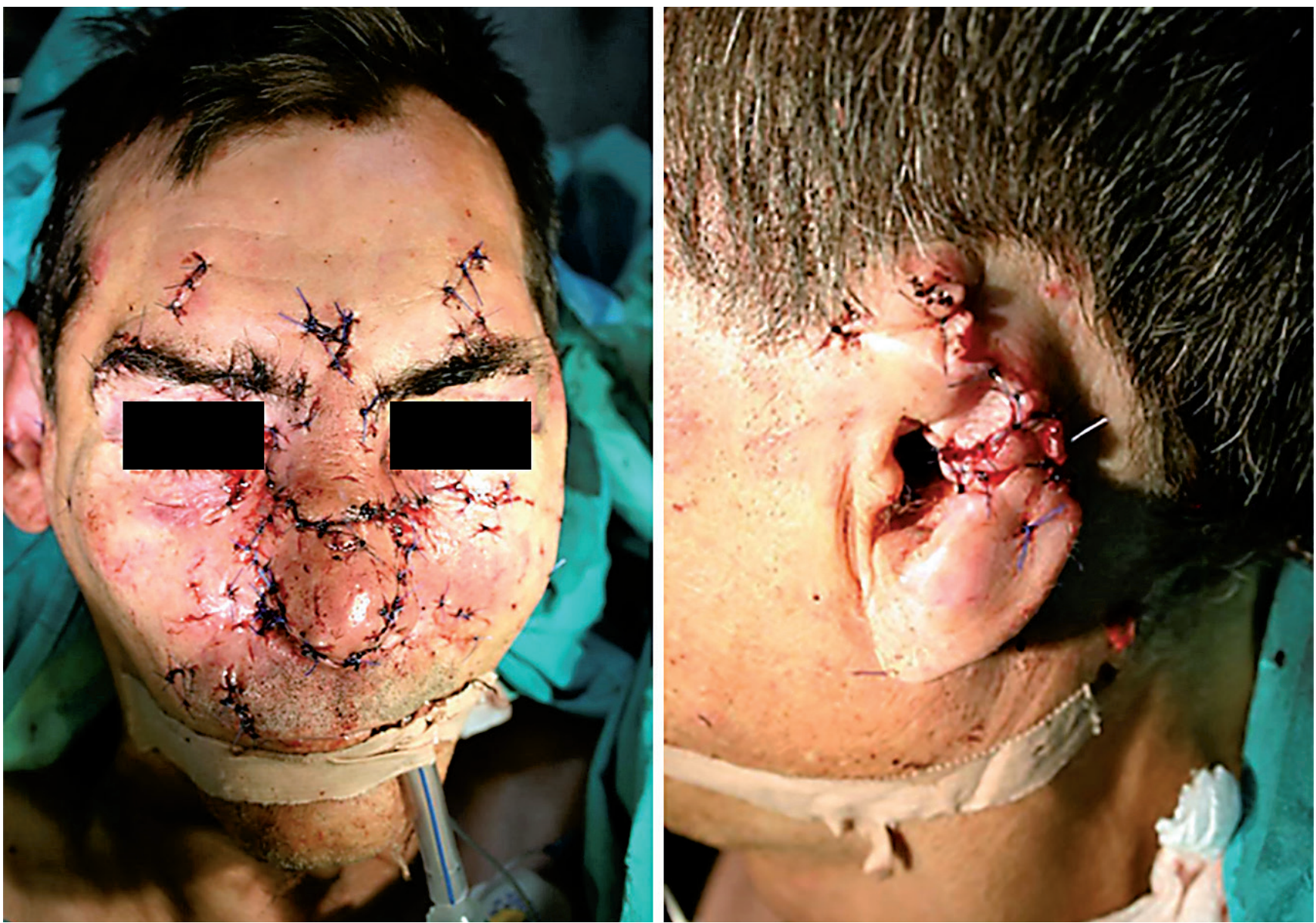

Fig. 2. Man, 36 years old. Numerous facial wounds of all facial regions

tients had concomitant soft tissue injuries, whereas 5 individuals suffered from injuries covering other areas of the body. The most frequently observed concomitant injuries include chest injuries (including rib and collarbone fractures).
Within the whole examined group, 18 patients were intoxicated. From among 22 examined women, 12 of them (0.55 fraction) suffered from injury after alcohol consumption. As far as masculine group is concerned, 7 men (0.54 fraction) were sober, whilst 6 people (0.46 fraction) were 

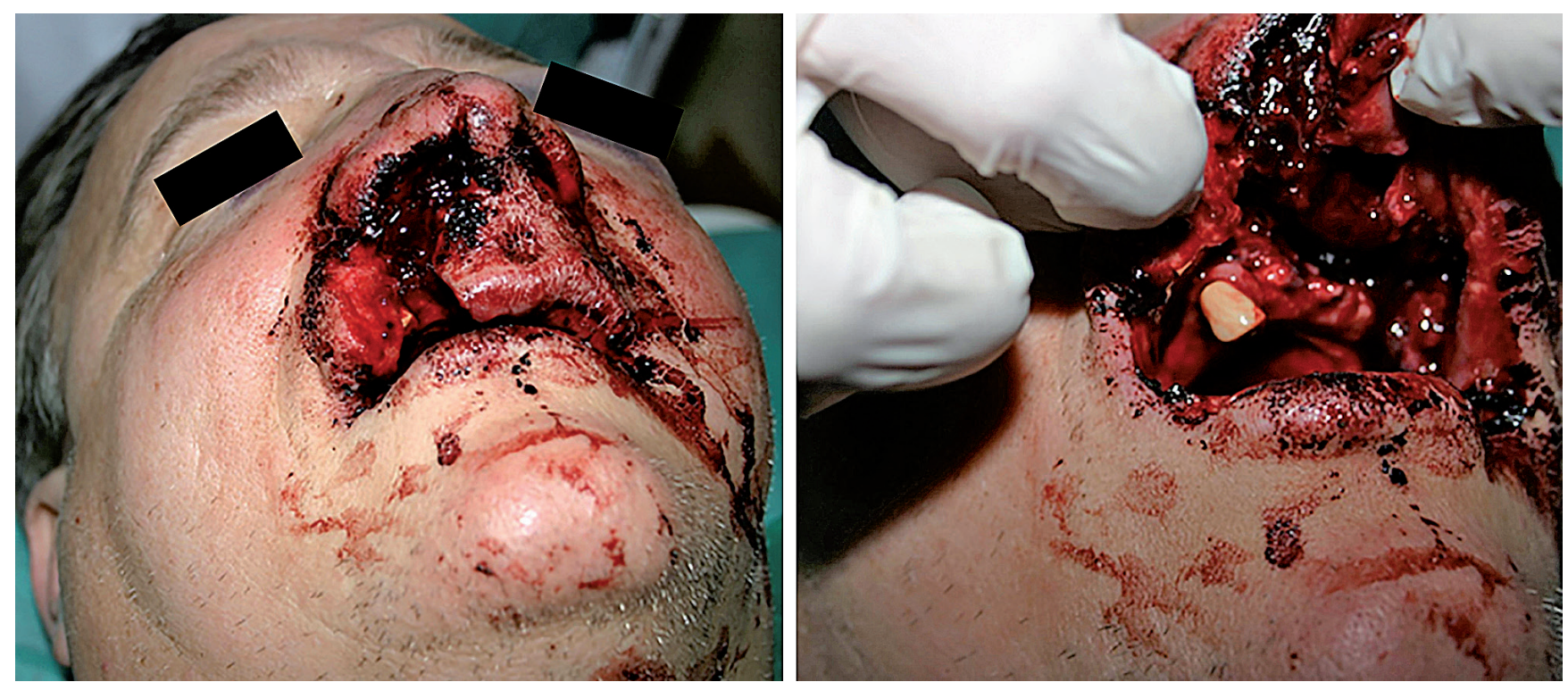

Fig. 3. Man, 54 years old - patient was hit by the horse's head. The wounds of the upper lip, nose, the mucous membrane of the oral cavity. Fracture of tooth crowns 14, 15. The total dislocation of teeth 12-26. The comminuted fracture of the nose, maxilla, left orbital floor fracture, zygomatico-maxillo-orbital fracture on the left side and fracture of left zygomatic arch

25

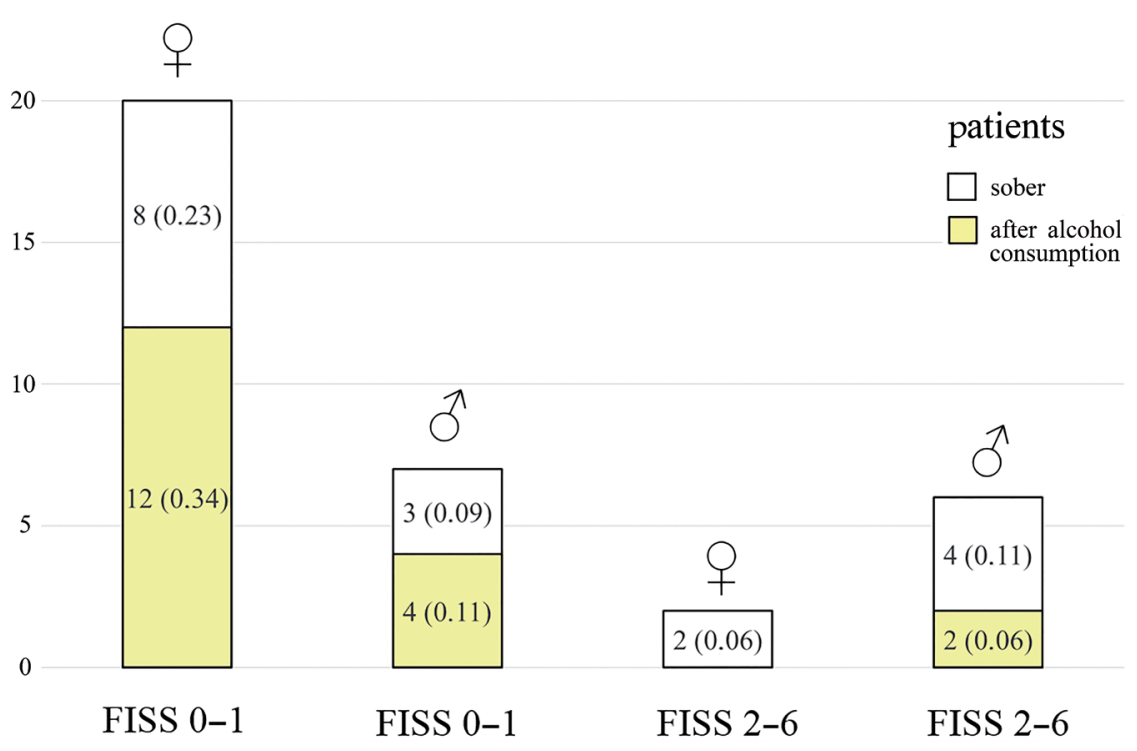

Fig. 4. Severity of the injuries according to the FISS scale in relation to alcohol consumption before the accident intoxicated at the moment when the incident happened. Nevertheless, no statistically significant dependence between alcohol consumption and the severity of the injury was stated (only 2 people suffered from injuries evaluated between 2 and 6 points on the FISS scale following alcohol consumption). Observations revealed that men experienced more severe injuries, as far as the FISS scale is concerned, significantly more often than women (Fig. 4).

The statistical significance between alcohol consumption and the animal responsible for the injury was declared $(\mathrm{p}<0.05)$. It was observed that significantly more intoxicated people than sober individuals suffered dog bites (0.89 fraction vs 0.59 fraction) (Table 2).
What was also observed is the fact that intoxicated people tended to have more than one area covered by the injury when compared with sober patients (fractions: 0.78 and 0.59) (Table 3). This difference did not prove statistically significant $(\mathrm{p}>0.05)$.

Analysis focusing on the dependence between the severity of the trauma and the site of the accident revealed statistical significance $(\mathrm{p}<0.01)$. It was proved that men were much more often injured in accidents taking place on agricultural farms than women (fraction 0.54 vs 0.09). On the other hand, women more often suffered from injuries in sites other than agricultural farms, such as: streets and households $(0.91$ vs 0.46$)$. It was also observed that 
Table 2. Alcohol consumption and the animal that caused the injury

\begin{tabular}{|c|c|c|c|c|c|}
\hline \multirow{3}{*}{$\begin{array}{l}\text { Animal that } \\
\text { caused the } \\
\text { injury }\end{array}$} & \multicolumn{4}{|c|}{ Alcohol } & \multirow{3}{*}{ Total } \\
\hline & \multicolumn{2}{|c|}{ yes } & \multicolumn{2}{|c|}{ no } & \\
\hline & $\mathrm{N}$ & fraction & $\mathrm{n}$ & fraction & \\
\hline Horse & 2 & 0.11 & 6 & 0.35 & 8 \\
\hline Bull & - & - & 1 & 0.06 & 1 \\
\hline Dog & 16 & 0.89 & 10 & 0.59 & 26 \\
\hline Total & 18 & 1,00 & 17 & 1.00 & 35 \\
\hline
\end{tabular}

$p<0.05$
Table 4. Severity of trauma in relation with the site of the accident (based on the pie chart)

\begin{tabular}{|c|c|c|c|c|c|}
\hline \multirow{3}{*}{$\begin{array}{l}\text { Site of the } \\
\text { accident }\end{array}$} & \multicolumn{4}{|c|}{ Severity of trauma } & \multirow{3}{*}{ Total } \\
\hline & \multicolumn{2}{|c|}{ FISS 0-1 } & \multicolumn{2}{|c|}{ FISS 2-6 } & \\
\hline & $n$ & fraction & $\mathrm{n}$ & fraction & \\
\hline Agricultural farm & 0 & 0 & 8 & 0.23 & 8 \\
\hline $\begin{array}{l}\text { Other sites where } \\
\text { accidents happen: } \\
\text { city, streets, home }\end{array}$ & 26 & 0.74 & 1 & 0.03 & 27 \\
\hline Total & 26 & 0.74 & 9 & 0.26 & 35 \\
\hline
\end{tabular}

Table 3. Number of injured facial areas depending on alcohol consumption

\begin{tabular}{|c|c|c|c|c|c|}
\hline \multirow{3}{*}{$\begin{array}{l}\text { Number } \\
\text { of injured } \\
\text { facial areas }\end{array}$} & \multicolumn{4}{|c|}{ Alcohol } & \multirow{3}{*}{ Total } \\
\hline & \multicolumn{2}{|c|}{ yes } & \multicolumn{2}{|c|}{ no } & \\
\hline & $n$ & fraction & $\mathrm{n}$ & fraction & \\
\hline 1 & 4 & 0.22 & 7 & 0.41 & 11 \\
\hline$>1$ & 13 & 0.78 & 6 & 0.59 & 19 \\
\hline Total & 17 & 1.00 & 13 & 1.00 & 30 \\
\hline
\end{tabular}

$\chi^{2}=2.915 ; p>0.05$

injuries of greater severity were significantly more frequently associated with agricultural farms (Table 4).

Observations focusing on the subgroup of patients with facial wounds revealed that intoxicated people had more than one area injured when compared with sober patients (fractions: 0.78 and 0.59). However, this occurred only slightly more frequently and this difference did not prove statistically significant $(\mathrm{p}>0.05)$.

As far as the study group is concerned, the average hospitalization period in the case of patients treated for animal related injuries lasted 5 days (standard deviation reaching 7.92 days). The length of the hospitalization period depended on the severity of the trauma. In the case of more severe injuries (FISS 2-6), the period of patients' hospitalization was considerably longer $(\mathrm{z}=3.928 ; \mathrm{p}<0.001)$ than it was the case among patients, whose injuries were evaluated as $0-1$ on the FISS scale. Respective averages equal $14.6 \pm 12.8$ days vs $2.2 \pm 1.96$ days. Half of the patients with more severe injuries stayed in the hospital for longer than 9 days, whereas individuals suffering from 0-1 FISS injuries were hospitalized for 1 day.

\section{Discussion}

There is not a considerable number of titles in literature related to the topic of animal related injuries - especially as far as injuries of the head and neck are concerned. This seems to be a result of the noticeable prevalence of such injuries, which only involve epidermal abrasions and slight wounds that do not require surgical intervention. Chomel et al.state that up to 37.5 people per 100,000 will suffer from animal related injuries. ${ }^{10}$ On the basis of the available literature, it is essential to emphasize that the kind of animals causing injuries depends on the environmental and demographic factors. Depending on the climatic zone, as well as the scope of urbanization within the given region, authors tend to write about injuries caused by animals such as camels, snakes or scorpions in their research. ${ }^{11,12}$ When injuries that city dwellers suffer from are taken into consideration, other animals are cited as the cause of injuries - the most commonly mentioned animals in this case include home animals, such as dogs and cats, etc. Quite different animals cause injuries among rural inhabitants, which is due to the prevalent dominance of larger animals (farm animals such as horses, cows, etc.). ${ }^{13}$ The literature also covers injuries associated with human migration. ${ }^{13}$

The majority of research, similarly to our study, mentions dogs as being the animal that most frequently causes injuries to people (amounting up to more than $80 \%$ of all cases). ${ }^{13-18}$ This is due to the popularity of dogs as home animals - according to studies, there are more than 77.5 million dogs registered only in the USA. This is also the country where about 9,500 incidences of hospitalization exceeding 1-day period due to dog bites is observed. Dogs mainly cause slight injuries. Despite this fact, we can see alarming data reported in North America, where until the year 2006 more than 500 deaths related to dog bites were noted. ${ }^{4,5,19}$

Slightly more than a half of injuries among patients from the discussed group involved intoxicated people. A noteworthy majority of injuries caused by dogs happened to people who drank alcohol prior to the accident. The studied group revealed a tendency indicating that alcohol consumption was related to the occurrence of more severe injuries, next to a greater number of injured areas. Certain authors emphasize that repeatedly; the attack of the animal was preceded by certain factors evoking animal aggression. Circumstances favoring the attack of the animal include: feeding, taking care of the offspring, playing, as well as protecting against another animal. ${ }^{20}$ Patronek emphasizes that, apart from the lack of proper 
behavior in human-animal relation, abuse of psychoactive drugs, including alcohol, by the animal owner or bite victims, stand as important factors underlying deadly dog bite related injuries. ${ }^{21}$ The available literature lacks proper research concerning the dependence between the severity of animal related injuries and the fact that the victim drank alcohol before the accident.

In most of our patients, we introduced antibiotic prophylaxis with the use of amoxycillin with clavulanic acids and we did not observe any inflammation complication. However, the literature data on this topic is not consistent. Some authors indicate that there is no statistical evidence that antimicrobial prophylaxis is effective. ${ }^{22,23}$ Others, recommend such therapy for older patients and patients with comorbidities, high-risk injuries like cats, horses, and birds bites, puncture wounds, extensive injuries, trauma in babies and infants and in the case of delayed surgical treatment of animal related wounds. ${ }^{22,24-27}$ Some authors strongly contraindicate antibiotic prophylaxis in case of scratch wounds and excoriations. ${ }^{28}$ Others state that prophylaxis should be administered to all bite wounds after primary closure. ${ }^{29,30}$ Based on abovementioned articles, it seems also that there is a great variety of antibiotics chosen for prophylaxis. All clinically infected wounds should be cultured. ${ }^{31}$ From the studies that have examined bacterial isolates from bite wounds it is known that cat and dog bite infections are polimicrobial. ${ }^{32,33}$ Pasteurellae and Bacteroides spp. predominate in early wounds, and, in those presenting after $24 \mathrm{~h}$ after the event, staphylococci or anaerobes are frequently present. ${ }^{34,35}$ Therefore, the prophylactic antibiotic should be a broad spectrum antibiotic, in which case co-amoxiclav seems to be a drug of choice. ${ }^{36}$ The alternative prophylaxis for patients allergic to penicillin include tetracyclines, a second generation of cephalosporin with anaerobic activity, or combination therapy with clindamycin and fluoroquinolone. ${ }^{31}$

In the case of bite wounds, there is a threat of inflammatory complications, so careful debridement of necrotic tissue and wound toilet are always required. ${ }^{37-40}$ Primary closure seems to be the method of choice. The more complicated soft tissue injuries should be reconstructed with local flaps, mucosa advancement, full thickness grafts. ${ }^{41}$ In some cases, microvascular reconstructions with free flaps are good treatment options. ${ }^{42,43}$

Results of this report lead to observations enabling us to declare that men suffered from injuries reported as severe according to the FISS scale much more frequently than women. More severe injuries also occurred significantly more often in agricultural farms. The obtained data are compliant with those presented by other authors. It was also observed that a greater risk of animal caused injury and death relates to men than to women. ${ }^{44,45}$ Injuries caused by large home animals are related with the incidence of the so-called high-energy injuries and stand as frequent multi-organ and multi-site injuries. ${ }^{13,45-48}$

\section{Conclusions}

Animal related injuries are often multi-organ and multi-site injuries that require specialist treatment. More severe injuries were observed both in the masculine group and within the area of agricultural farms. The greater value of the FISS scale was associated with a longer period of hospitalization. Alcohol consumption is emphasized as factor prompting the attack of the animal, as well as animal aggression against a human being.

\section{References}

1. Abu-Zidan FM, Hefny AF, Eid HO, Bashir MO, Branicki FJ. Camelrelated injuries: Prospective study of 212 patients. World J Surg. 2012;36:2384-2389.

2. Shafaat R, Gh N, Manzoor A, Bashir A. Injuries from bear (Ursus thibetanus) attacks in Kashmir. Turk J Trauma Emerg Surg. 2009;15:130-134.

3. Adams A, Suton J, Elixhauser A. Emergency department visits and hospitalization associated with animal injuries. 2009. HCUP Statistical Brief 134, 2012, May.

4. Holmquist L, Elixhauser A. Emergency department visit and inpatient stays involving dog bites, 2008. Agency for Healthcare Research and Quality, Rockville, 2010, November.

5. Sacks JJ, Sinclair L, Gilchrist J, Golab GC, Lockwood R. Breeds of dogs involved in fatal human attacks in the United States between 1979 and 1998. J Am Vet Med Assoc. 2000;15:836-840.

6. Accidents at work, occupational diseases of farmers and preventive actions of KRUS in 2012. Kasa Rolniczego Ubezpieczenia Społecznego (KRUS). Warszawa, 2013.

7. Rzepecka-Woźniak E. Fatal dog bites. Arch Med Sąd Krym. 2006;56: 56-60.

8. Manowska B, Arkuszewski P, Tyndorf M. Review of post-traumatic injuries in patients who received ambulatory emergency treatment. Czas Stomatol. 2009;62:134-140 [in Polish].

9. Bagheri SC, Dierks EJ, Kademani D, et al. Application of a facial injury severity scale in craniomaxillofacial trauma. J Oral Maxillofac Surg. 2006;64:408-414.

10. Chomel BB, Trotignon J. Epidemiologic surveys of dog and cat bites in the Lyon area, France. Eur J Epidemiol. 1992;8:619-624.

11. Ugboko VI, Olasoji HO, Ajike SO, Amole AOD, Ogundipe OT. Facial injuries caused by animals in northern Nigeria. Br J Oral Maxillofac Surg. 2002;40:433-437.

12. Alavi SM, Alavi L. Epidemiology of animal bites and stings in Khuzestan, Iran, 1997-2006. J Infect Public Health. 2008;1:51-55.

13. Nogalski A, Jankiewicz L, Ćwik G, Karski J, Matuszewski L. Animal related injuries treated at the Department of Trauma and Emergency Medicine, Medical University of Lublin. Ann Agric Environ Med. 2007;14:57-61.

14. MacBean CE, Taylor DM, Ashby K. Animal and human bite injuries in Victoria 1998-2004. Med J Aust. 2007;186:38-40.

15. Weis HB, Friedman DI, Coben JH. Incidence of dog bite injuries treated in emergency departments. JAMA 1998;279:51-53.

16. Hon KL, Fu CC, Chor CM, Tang PS, Leung TF, Man CY. Issues associated with dog bite injuries in children and adolescents assessed at the emergency department. Pediatr Emerg Care. 2007;23: 445-449.

17. Ndon JA, Jack GV, Wehrenberg WB. Incidence of dog bites in Milwaukse, Wis. Wis Med J. 1996;95:237-241.

18. Shetty RA, Chaturvedi S, Singh Z. Profile of animal bite cases in Pune. J Commun Dis. 2005;37:66-72.

19. Dog bite prevention. Injury prevention \& control: Home and recreational safety. Centers for Disease Control and Prevention, 2009, May.

20. Injuries associated with dog bites and dog attacks. Canadian Hospitals Injury Reporting and Prevention Program - CHIRPP database, 1996.

21. Patronek GJ, Sacks JJ, Delise KM, Cleary DV, Marder AR. Co-occurrence of potentially preventable factors in 256 dog bite-related fatalities in the United States (2000-2009). J Am Vet Med Assoc. 2013;243:1726-1736. 
22. Wolff KD. Management of animal bite injuries of the face: Experience with 94 patients. J Oral Maxillofac Surg. 1998;56:838-843.

23. Callaham M. Prophylactic antibiotics in common dog bite wounds: A controlled study. Ann Emerg Med. 1980;9:410-414.

24. Correira K. Managing dog, cat, and human bite wounds. JAAPA. 2003;16:28-37.

25. Scheithauer MO, Rettinger G. Bite injuries in the head and neck area. HNO 1997;45:891-897.

26. Goldstein EJ. Current concepts on animal bites: Bacteriology and therapy. Curr Clin Top Infect Dis. 1999;19:99-111.

27. Metzger R, Kanz KG, Lackner CK, Mutschler W. After cat bite antibiotics are obligatory acute management of bite injuries. MMW Fortschr Med. 2002;144:46-49.

28. Dire DJ, Hogan DE, Walker JS. Prophylactic oral antibiotics for low risk dog bite wounds. Pediatr Emerg Care. 1992;8:194-199.

29. Baxter DN. The deleterious effects of dogs on human health: Dogassociated injuries. Commun Med. 1984;6:29.

30. Moore F. I've just been bitten by a dog. BMJ. 1997;314:88-89.

31. Morgan M. Hospital management of animal and human bites J Hosp Infect. 2005;61:41-50.

32. Weber DJ, Hansen AR. Infections resulting from animal bites. Infect Dis Clin North Am. 1991;5:663-680.

33. Brook I. Microbiology of human and animal bite wounds. Am Fam Phys. 1987;141:703-705.

34. Goldstein EJC, Barones MF, Miller TA. Eikenella corrodens in hand infections. J Hand Surg (Am). 1983;8:563-567.

35. Lion C, Lozniewski A, Rosner V, Weber M. Lung abscess due to beta-lactamase producing Pasteurella multocida. Clin Infect Dis. 1999;29:1345-1346.

36. Goldstein EJ, Citron DM. Comparative susceptibilities of 173 aerobic and anaerobic bite wound isolates to sparfloxacin, temafloxacin, clarithromycin and older agents. Antimicrob Agents Chemother. 1993;37:1150-1153.
37. Harris D, Imperato P, Oken B. Dog bites;an unrecognised epidemic. Bull N Y Acad Med. 1974;50:981-984.

38. Sacks JJ, Lockwood R, Hornreich J, Sattin RW. Fatal dog attacks 1981-94. Pediatrics 1996;9:891-895.

39. Barnham M. Once bitten twice shy; the microbiology of animal bites. Rev Med Microbiol. 1991;2:231-236.

40. Wright JC. Reported cat bites in Dallas. Characteristics of the cats, the victims and the attack events. Public Health Rep. 1990;105:420-424.

41. Javaid M, Feldberg L, Gipson M. Primary repair of dog bites to the face: 40 cases. J R Soc Med. 1998;3:414-416.

42. Burt JD, Burns AJ, Muzaffar AR, Byrd HS, Hobar PC, Beran SJ. Total soft-tissue reconstruction of the middle and lower face with multiple simultaneous free flaps in a pediatric patient. Plast Reconstr Surg. 2000;105:2440-2447.

43. Lengele BG, Testelin S, Bayet B, Devauchelle B. Total lower lip functional reconstruction with a prefabricated gracilis muscle free flap. Int J Oral Maxillofac Surg. 2004;33:396-401.

44. Morris JA Jr, MacKenzie EJ, Damiano AM, Bass SM. Mortality in trauma patients: The interaction between host factors and severity. J Trauma. 1990;30:1476-1482.

45. Presutti RJ. Bite wounds. Early treatment and prophylaxis against infectious complications. Postgrad Med. 1997;101:243-244, 246$252,254$.

46. Wiggins P, Schenker MB, Green R, Samuels S. Prevalence of hazardous exposures in veterinary practice. Am J Ind Med. 1989;16:55-66.

47. Busch HM Jr, Cogbill TH, Landercasper J, Landercasper BO. Blunt bovine and equine trauma. J Trauma. 1986;26:559-560.

48. Conrad L. The maul of the wild. Animal attacks can produce significant trauma. Emerg Med Serv. 1994;23:71-72, 76 